\title{
Piotr Köhler
}

Zakład Badań i Dokumentacji Polarnej im. Prof. Z. Czeppego

Instytut Botaniki UJ, Kraków

\section{POLSKA WYPRAWA NA SPITSBERGEN W 1938 R.}

\author{
Polish Expedition to Spitsbergen in 1938
}

Polish expedition to Spitsbergen in 1938 was the fifth Polish expedition to the Arctic during interwar period. Four persons participated in it: geologist Bronisław Halicki (1902-1962) from Stefan Batory University in Vilnius, geographer and geomorphologist Mieczysław Klimaszewski (1908-1995) from the Jagiellonian University in Kraków, geologist Ludwik Sawicki (1893-1972), connected with the State Geological Institute in Warsaw, and Stefan Bernardzikiewicz (1907-1939) from the Warsaw Technical University (organizer and technical leader of the expedition).

Polish expedition stayed from July $5^{\text {th }}$ to September $6^{\text {th }} 1938$ on the Oscar II Land on Spitsbergen. The basis was set up on the Kaffioyr plain. Research was conducted within up to $100 \mathrm{~km}$ radius from the base. The main purpose of the expedition was to collect possibly enough data for comparison purposes that could enable studies of the Pleistocene deposits in Poland.

The $2^{\text {nd }}$ World War prevented researchers from working on the collected data and from publishing them. Only in 1960, M. Klimaszewski published a valuable geomorphological study devoted to the territory located between Kongsfjorden and Eidembukta. The data and experience obtained on Spitsbergen were of great importance for later interpretations, both Old Quarternary and Young Pleistocene, as well as Holocene geological profiles on the Polish Lowlands.

Keywords: Arctic; Spitsbergen; Polish expeditions

Słowa kluczowe: Arktyka; Spitsbergen; polskie wyprawy 
W drugiej połowie okresu międzywojennego Polska prowadziła intensywne (jak na ówczesne swe możliwości) badania Arktyki za pomocą ekspedycji naukowych. Pierwsza polska wyprawa polarna odbyła się w latach 1932-1933 w ramach II Międzynarodowego Roku Polarnego. Przez rok zbierano wtedy na Wyspie Niedźwiedziej dane meteorologiczne oraz prowadzono pomiary natężenia promieni słonecznych, magnetyzmu ziemskiego, zorzy polarnej i elektryczności atmosferycznej ${ }^{1}$. Następna wyprawa zorganizowana została w 1934 r. Jej celem było zbadanie Ziemi Torella na Spitsbergenie. Wykonano tam prace topograficzne, geologiczne, sporządzono mapy tego terenu, zebrano także materiały botaniczne i zoologiczne ${ }^{2}$. Trzecia z kolei wyprawa odbyła się w 1936 r. Ekspedycja ta miała być rodzajem rekonesansu $\mathrm{z}$ elementami alpinistycznymi i naukowymi, a była $\mathrm{w}$ istocie pierwszym $\mathrm{w}$ historii pełnym trawersem Spitsbergenu z południa na północ ${ }^{3}$. Czwarta wyprawa udała się

\footnotetext{
${ }^{1}$ Najnowsze publikacje na temat tej wyprawy: M. G ó r s ki: Zimowanie 1932/1933 na Wyspie Niedźwiedziej - eksplozja polskich badań polarnych. „Przegląd Geofizyczny” 2015 nr 1-2 s. 59-76; P. Kö hl e r: Osiemdziesięciolecie polskiej wyprawy na Wyspę Niedźwiedziq̨. „Biuletyn Polarny” 2014 nr 17-18 s. 62-66; P. Köhler: Pierwsza polska wyprawa polarna. „Kwartalnik Historii Nauki i Techniki" 2013 t. 58 nr 4 s. 43-59; P. Kö hl e r: The first Polish expedition to the Arctic. [w:] The Arctic Science Summit Week 2013 "The Arctic Hub Regional and Global Perspectives", 13-19 April 2013, Kraków, Poland. 2013 [publikacja elektroniczna], s. 1; P. Köhler: Z Legionowa na Wyspę Niedźwiedziq. I polska wyprawa polarna 1932-1933. „Rocznik Legionowski” 2014 t. 7 s. 30-38; P. Köhler, M. Ko rczak-Abshire: Sesja naukowa „Znaczenie pierwszej wyprawy polarnej z Polski niepodległej”. Jubileusz 80-lecia Polskiej Ekspedycji II Międzynarodowego Roku Polarnego 1932/1933 na Wyspę Niedźwiedziq̨. „Kwartalnik Historii Nauki i Techniki” 2013 t. 58 nr 2 s. 268-271; A. Krawczyk: Polskie ślady na Wyspie Niedźwiedziej (1932-1933). „Biuletyn Polarny” 2014 nr 17-18 s. 73-75; S. Maj: Pierwsza polska wyprawa polarna na Wyspę Niedźwiedzią (1932-1933). „Przegląd Geofizyczny” 2014 nr 3-4 s. 175-186; J. S z u p r y c z y ń s k i : Pierwsza polska wyprawa polarna. „Przegląd Geograficzny" 2013 t. 85 nr 1 s. 123-130.

${ }^{2}$ Najnowsze publikacje na temat tej wyprawy: H. Gurgul, M. Krzeptowski : Henryk Mogilnicki (1906-1999) w 65-lecie Polskiej Wyprawy na Spitsbergen. „Biuletyn Polarny” 2000 nr 8 s. 48-49; P. Köhler: Polish expedition to Torell Land, Spitsbergen, in 1934 in the light of archival materials. [w:] K. Migała, M. C. Strzelecki, P. Owczarek, T. Sawiński, M. Korzystka-Muskała, P. Muskała, M. Kasprzyk (red.): Book of abstracts. 35th Polar Symposium Diversity and state of polar ecosystems. 4th-7th June 2014, Wrocław. Institute of Geography and Regional Development, University of Wrocław, Wrocław 2014 s. 62; P. Köhle r: Polska wyprawa na Spitsbergen w 1934 roku. „Kwartalnik Historii Nauki i Techniki" 2015 t. 60 nr 2 s. 117-140; J. S z u p ry c zyń ski : Pierwsza polska wyprawa polarna na Spitsbergen. „Przegląd Geograficzny” 2015 t. 87 nr 1 s. 167-178.

${ }^{3}$ [a n o n i m ]: II Polska wyprawa na Spitsbergen 1936 r., „Taternik” 1936 t. 21 nr 1 s. 11-12; S. B e rnadziki ewicz: II Polska wyprawa na Spitsberg, „Turysta w Polsce” 1936 t. 2 nr 11 s. 10-11; Z. Dą b row s ki : Polska wyprawa na Spitsbergen 1936 r., „Taternik” 1936 t. 20 nr 6 s. 220-221; P. Köhler: Osiemdziesięciolecie polskiej wyprawy na Wyspę Niedźwiedzią, „Biuletyn Polarny” 2014 nr 17-18 s. 62-66; P. Köhler: Druga polska wyprawa na Spitsbergen (w 1936 roku), „Kwartalnik Historii Nauki i Techniki” 2016 t. 61 nr 4 s. 135-143; P. Kö hle r: Druga polska wyprawa na Spitsbergen ( $w 1936$ roku). The second Polish expedition to Spitsbergen (in 1936), [w:] Ł. Francza k, G. Gaje k (red.): XXXVI Sympozjum Polarne "Progress in polar research - new experiences and challenges" 30-lecie Wypraw Polarnych
} 
w 1937 r. na Grenlandię, gdzie w fiordzie Arfersiorfik prowadzono kompleksowe badania z zakresu geomorfologii, geologii, glacjologii, pedologii, botaniki i meteorologii ${ }^{4}$. Ostatnia przed wybuchem II wojny światowej polska wyprawa polarna odbyła się w 1938 r. ponownie na Spitsbergen.

Polska wyprawa nie była jedyną ekspedycją działającą w lecie 1938 roku na Spitsbergenie. W okolicach fiordu Hornsund przebywała m.in. niemiecka ekspedycja, mająca podobne zadania glacjologiczne i kartograficzne ${ }^{5}$.

W przeciwieństwie do wcześniejszych polskich wypraw do Arktyki, które posiadają dość bogatą literaturę dokumentacyjną i pamiętnikarską ${ }^{6}$, wyprawa z $1938 \mathrm{r}$. takiej dokumentacji prawie nie ma. Dlatego w danych o przygotowaniach do tej ekspedycji i jej przebiegu są spore luki. Poniżej przedstawiona jest organizacja wyprawy, a następnie jej przebieg i rezultaty na podstawie dostępnych nielicznych publikacji.

UMCS na Spitsbergen. Ksiqż̇ka streszczeń, Wydział Nauk o Ziemi i Gospodarki Przestrzennej UMCS, Lublin 2016, s. 53; S. S i e d l e c ki : Przejście z południa na północ przez Zachodni Spitsbergen, „Wierchy” 1938 t. 16 s. 118-135.

${ }^{4}$ S. B e rnadziki e wi cz: Wielki sukces polskiej wyprawy Polarnej, „Ilustrowany Kuryer Codzienny" (Kraków) 1937 (22 X) s. 22; A. B. D o b row ols ki : Pierwsza polska wyprawa do Grenlandii zachodniej, „Wiedza i Życie” 1948 t. 17 nr 6-7 s. 605-608; A. Ga we ł : Z dziennika wyprawy naukowej na Grenlandię w 1937 roku, „Prace Muzeum Ziemi” 2001 t. 46 s. 171-184; A. J a h n: Grenlandia Zachodnia terenem polskiej wyprawy naukowej, „Wszechświat” r. $1938 \mathrm{nr}$ 3 s. 67-73; P. Kö hl le r: Polska wyprawa na Grenlandię w 1937 r., „Kwartalnik Historii Nauki i Techniki” 2017 t. 62 nr 4 s. 45-63; A. Ko s i b a: Mapa pierwszej wyprawy naukowej na Grenlandię, „Czasopismo Geograficzne” 1939 t. 17 nr 1 s. 37-38; A. Ko siba: O udziale Polaków w badaniach Grenlandii, „Czasopismo Geograficzne” 1973 t. 44 nr 2 s. 147-188; A. Ko sib a: I. polska wyprawa na Grenlandię, „Czasopismo Geograficzne” 1937 t. 15 nr 3 s. 209-213; [A. K o s i b a ]: Polish Expedition to West Greenland, 1937, „The Polar Record” (Scott Polar Research Institute, Cambridge) 1938 t. 2 nr 14 s. 117-118, nr 15 s. 25-27; A. Ko s i b a: Polska wyprawa na Grenlandię w r. 1937. (Komunikat wstępny). Polish Greenland - expedition. (Preliminary report), Towarzystwo Geograficzne we Lwowie [Lwów 1937] ss. 8; A. Zawa d zki : Polska Wyprawa na Grenlandię, „Wiadomości Służby Geograficznej” 1937 t. 11 nr 2 s. 235-237; A. Zawadzki : Polska Wyprawa na Grenlandię w r. 1937, „Wiadomości Służby Geograficznej" 1938 t. 12 nr 1 s. 33-73, nr 2-3 s. 166-214, nr 4 s. 508-521; A. Zawadzki: Polska wyprawa na Grenlandię 1937, Nakł. Sekcji Geograficznej Tow. Wiedzy Wojskowej, Warszawa 1939 ss. VI + nlb. $1+102+$ nlb. 1, tabl. 4, mapa 1. [Seria: Biblioteka Służby Geograficznej, t. 18]; A. R. Zawadzki: Polska wyprawa na Grenlandię w 1937 r. Polish Greenland Expedition 1937, Nakładem Sekcji Wydawniczej Armii Polskiej na Wschodzie, [Palestyna] 1944 s. 31; A. Z a wa d z ki : Prace polskiej wyprawy naukowej na Grenlandię w 1937 r., „Wiadomości Służby Geograficznej" 1937 t. 11 nr 3-4 s. 507-520.

${ }^{5}$ W. Pill e w i z e r: Die kartographischen und gletscherkundlichen Ergebnisse der deutschen Spitzbergen-Expedition 1938, Justus Perthes Verlag Gotha 1939 s. 1-46; K. Ruth e: Bericht über die kartographischen und gletscherkundlichen Ergebnisse der Deutschen Spitzbergen-Expedition 1938, „Polarforschung” (Bremerhaven) 1941 t. 11 nr 1 s. 6-8.

${ }^{6} \mathrm{O}$ czym świadczą cytowane opracowania w poprzednich przypisach. 


\section{Organizacja wyprawy}

Ekspedycja doszła do skutku dzięki Polskiemu Towarzystwu Wypraw Badawczych. Była to organizacja powstała 20 grudnia 1937 r. w Warszawie z inicjatywy Klubu Wysokogórskiego Polskiego Towarzystwa Tatrzańskiego. Należały do niej różne instytucje państwowe i prywatne, w tym Polskie Koło Polarne. Celem Polskiego Towarzystwa Wypraw Badawczych była pomoc dla zrzeszonych w nim stowarzyszeń i instytucji w organizowaniu wypraw badawczych ${ }^{7}$. Z tej pomocy jako jedno z pierwszych skorzystało Polskie Koło Polarne. Podczas posiedzenia zarządu Koła w dniu 4 (lub 5²) IV 1938 r. jego przewodniczący, a równocześnie znany i doświadczony badacz polarny, Antoni Bolesław Dobrowolski (1872-1954) poinformował o możliwości zorganizowania kolejnej wyprawy na Spitsbergen. Jej organizację należało rozpocząć od napisania odpowiedniego pisma oficjalnego do Polskiego Towarzystwa Wypraw Badawczych uzasadniającego potrzebę zorganizowania takiej ekspedycji. 0 przygotowanie pisma zwrócił się A.B. Dobrowolski do Ludwika Sawickiego (1893-1972), archeologa i geologa czwartorzędu, związanego wtedy z Państwowym Instytutem Geologicznym ${ }^{9}$.

Sawicki przygotował odpowiednie pismo. Powołał się w nim na dotychczasowe polskie badania Spitsbergenu i konieczność zachowania ich ciągłości. Wskazywał, że projektowana wyprawa ma na celu wyłącznie potrzeby polskiej geologii czwartorzędu, do których zaliczył zebranie obserwacji i innych danych z dziedziny glacjologii arktycznej, jako ważnych materiałów porównawczych w badaniach utworów glacjalnych i peryglacjalnych Polskiego Niżu. Wskazywał na małą znajomość wśród polskich badaczy problemów geologicznych towarzyszących współczesnemu zlodo-

${ }^{7}$ J. Węg low ski: Polskie Towarzystwo Wypraw Badawczych, [w:] B. S o r dyl ow a (red. naukowy): Słownik Polskich Towarzystw Naukowych, t. II Towarzystwa naukowe i upowszechniajace naukę działające w przeszłości na ziemiach polskich część 1, Zakład Narodowy im. Ossolińskich Wydawnictwo PAN Wrocław - Warszawa - Kraków - Gdańsk - Łódź 1990 s. 262-263.

${ }^{8}$ L. S a wi cki: Na Spitsbergen. Polska wyprawa glacjologiczna 1938 r., „Życie Warszawy” 1956 nr 132 (3-4 VI 1956) s. 6, nr 138 (10-11 VI 1956) s. 6, nr 144 (17-18 VI 1956) s. 6, cyt. nr 138 s. 6.

${ }^{9}$ [a n o n i m] : Wyprawa glacjologiczna na Spitsbergen. 5 czerwiec - 6 wrzesień $1938 r$., „Wyprawy i Podróże. Biuletyn Polskiego Towarzystwa Wypraw Badawczych" 1939 nr 1 s. 9-12, cyt. s. 9; M. Kl i m a s z e w s ki : Studia geomorfologiczne w zachodniej części Spitsbergenu między Kongs-Fjordem a Eidem-Bukta, „Zeszyty Naukowe Uniwersytetu Jagiellońskiego 32, (Prace Instytutu Geograficznego UJ 23) Prace Geograficzne - Seria Nowa" 1960 t. 1 s. 1-167, cyt. s. 7; Z. Wó j c ik: Zarys osiagnięć polskiej wyprawy glacjologicznej na Spitsbergen w 1938 r., [w:] Dzieje polskich, rosyjskich i radzieckich badań polarnych. Materiały III Sympozjum Polsko-Radzieckiego z Historii Nauk o Ziemi, Wrocław, 25-30 września 1978 r., Zakład Narodowy im. Ossolińskich, Wrocław - Warszawa - Kraków - Gdańsk - Łódź 1982, s. 201-227, cyt. s. 203; Z. J. Wó j c i k: Ludwik Sawicki. http://www.ipsb.nina.gov.pl/a/biografia/ludwik-sawicki [dostęp 24 III 2017] 
waceniu terenów arktycznych, a zwłaszcza charakteryzujących przedpola oraz terminalne partie lodowców polarnych. W przewidywaniu trudności w sfinansowaniu większej ekspedycji oraz po konsultacji z dyrektorem Norweskiego Instytutu do Badań Svalbardu i Mórz Polarnych (Norges Svalbard-og Ishavsundersøkelser) Adolfem Hoelem (1879-1964) ${ }^{10}$, Sawicki ograniczył teren prac wyprawy do odcinka o długości kilkudziesięciu kilometrów zachodniego wybrzeża Ziemi Oskara II na Spitsbergenie. Na tym terenie znajdowały się wszystkie elementy umożliwiające przeprowadzanie planowanych badań ${ }^{11}$. Pismo zawierające powyższe informacje, po uzyskaniu pozytywnych opinii paleontologa i geologa z Uniwersytetu Warszawskiego Romana Kozłowskiego (1889-1977), działacza społecznego i senatora RP Jana Lewandowskiego (1885-1960), profesora geologii z Uniwersytetu Stefana Batorego w Wilnie Edwarda Passendorfera (1894-1984) i profesora paleontologii z Uniwersytetu Jana Kazimierza we Lwowie Jana Samsonowicza (1888-1959) o potrzebie zorganizowania wyprawy, zostało przedstawione Polskiemu Towarzystwu Wypraw Badawczych $^{12}$. Na tej podstawie Polskie Koło Polarne otrzymało subwencję w wysokości 12950 zł na ekspedycję na Spitsbergen ${ }^{13}$. Oprócz tej dotacji wyprawa otrzymała także pomoc, już znacznie mniejszą, z innych instytucji, m.in. Państwowy Instytut Geologiczny pokrył koszty transportu zbiorów naukowych z Tromsø do Warszawy oraz ich transportu w Warszawie (w kwocie 300 zł). Część sprzętu obozowo-turystycznego pożyczono od Towarzystwa Geograficznego we Lwowie ${ }^{14}$, a Państwowy Instytut Meteorologiczny wypożyczył sprzęt meteorologiczny ${ }^{15}$.

\section{Uczestnicy}

Ze względu na fakt, iż program ekspedycji został ograniczony do zagadnień związanych ze zlodowaceniem Polskiego Niżu, do udziału w wyprawie zostali zaproszeni jedynie dwaj geologowie i geograf: doc. dr hab. Bronisław Halicki (1902-1962) (ryc. 1), geolog, adiunkt przy katedrze geologii Uniwersytetu Stefana Batorego w Wilnie ${ }^{16}$, dr Mieczysław Klimaszewski (1908-1995) (ryc. 2), geograf i geomorfolog,

${ }^{10}$ K. R. Lankauf: Recesja lodowców rejonu Kaffiøyry (Ziemia Oskara II - Spitsbergen) $w X X$ wieku. The retreat of the glaciers in the Kaffiøyra region (Oscar II Land-Spitsbergen) in the twentieth century, „Prace Geograficzne - Geographical Studies” 2002 t. 183, 221 s. + [18] k. tabl., [6] k. map złoż., cyt. s. 45.

${ }^{11}$ L. Sawicki: Polska wyprawa glacjologiczna w 1938 roku na Spitsbergen. (Kartki z Dziennika Wyprawy), „Acta Geophysica Polonica” 1959 t. 7 s. 405-418, cyt. s. 404-406.

${ }^{12}$ Z. Wó j c ik: Zarys osiagnięć..., s. 203-204.

${ }^{13}$ [a n o n i m ]: Wyprawa glacjologiczna na Spitsbergen..., s. 11; M. Kl i ma s z e w s ki: Studia geomorfologiczne w zachodniej części Spitsbergenu..., s. 7; L. S awi cki: Polska wyprawa glacjologiczna $w 1938$ roku..., s. 404-406.

14 [a n o n im ]: Wyprawa glacjologiczna na Spitsbergen..., s. 12.

${ }^{15}$ Z. Wó j ci k: Zarys osiagnięć.., s. 204.

${ }^{16}$ J. Dylik: Dr Bronisław Halicki - profesor Uniwersytetu Warszawskiego, „Czasopismo 


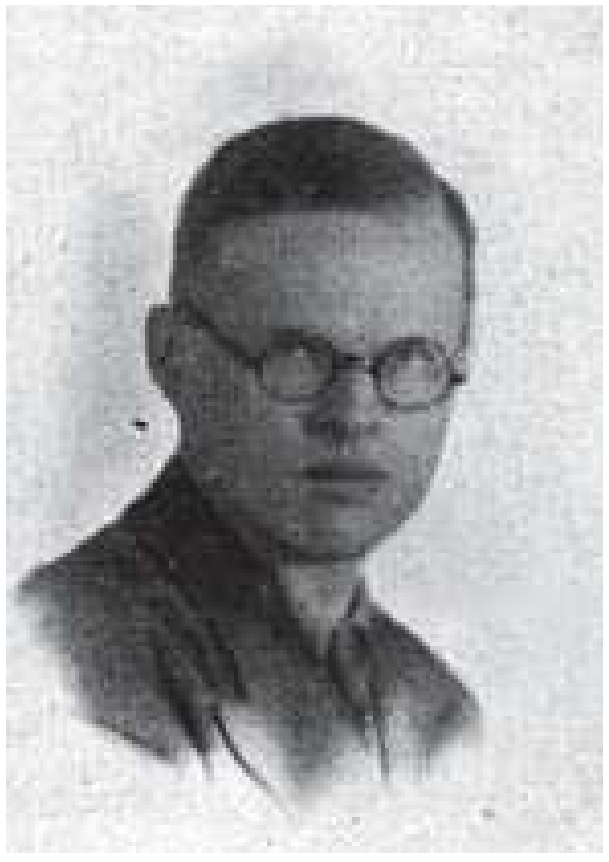

Ryc. 1. Bronisław Halicki (fot. anonim 1939)

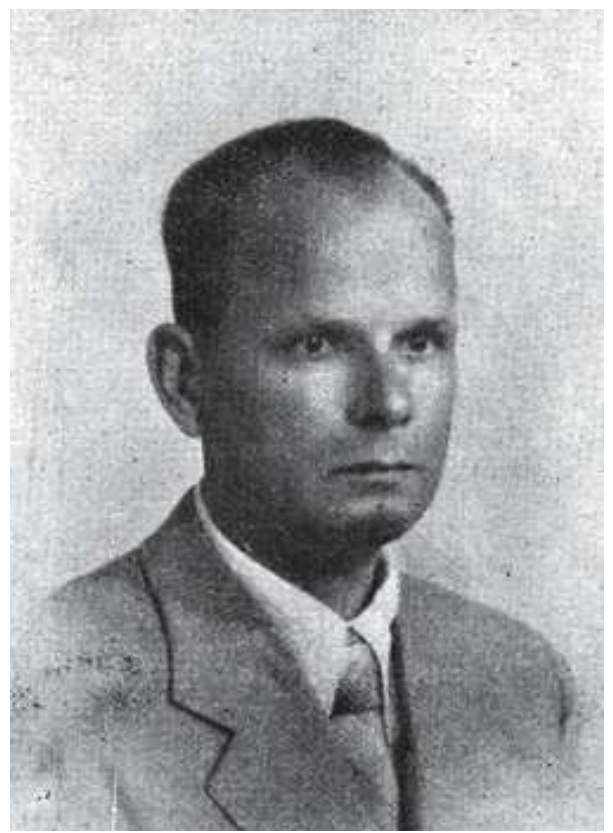

Ryc. 3. Ludwik Sawicki (fot. anonim 1939)

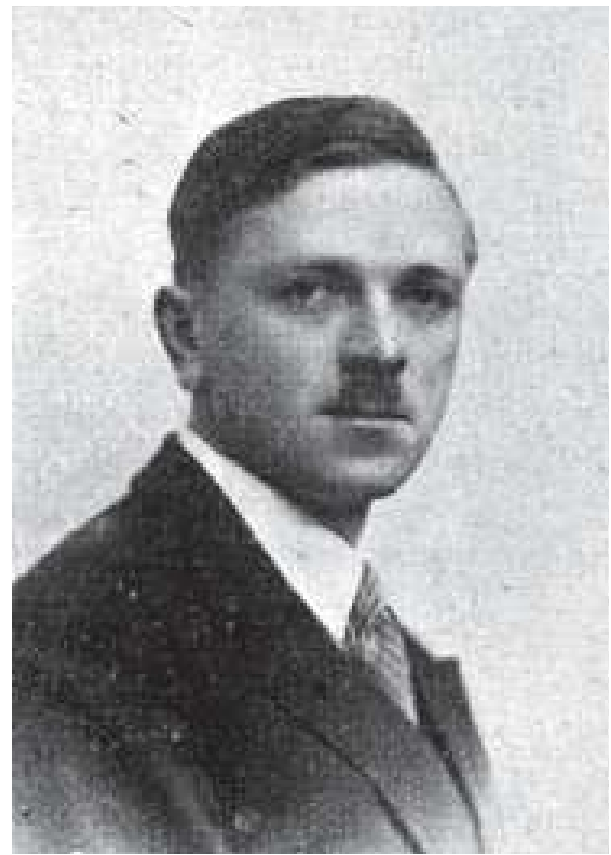

Ryc. 2. Mieczysław Klimaszewski (fot. anonim 1939)

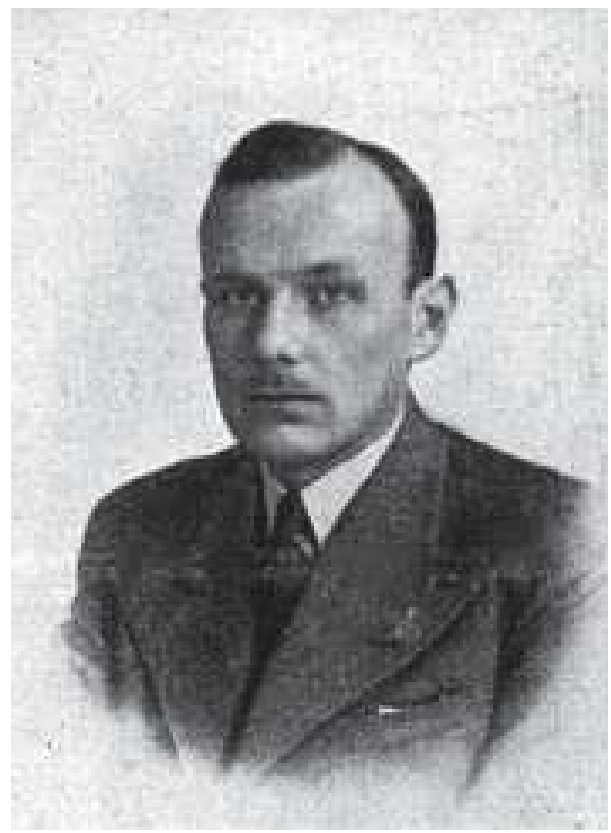

Ryc. 4. Stefan Bernadzikiewicz (fot. anonim 1939) 
asystent w Instytucie Geograficznym Uniwersytetu Jagiellońskiego ${ }^{17}$, i wspomniany już powyżej Ludwik Sawicki (ryc. 3). Kierownikiem organizacyjno-technicznym i skarbnikiem wyprawy został doświadczony taternik i polarnik, uczestnik polskich wypraw na Spitsbergen w $1934 r^{18}$ i $1936 r^{19}$ oraz na Grenlandię w $1937 r^{20}$, inż. Stefan Bernadzikiewicz (1907-1939) (ryc. 4), asystent w Zakładzie Metalurgicznym Wydziału Mechanicznego Politechniki Warszawskiej ${ }^{21}$. Zobowiązany był on także do prowadzenia badań meteorologicznych, zbierania okazów flory oraz do pomocy przy pracach w terenach górskich. W drugiej połowie pobytu wynajęto łódź motorową wraz z obsługą, którą stanowił mieszkający w osadzie górniczej Ny-Ålesund norweski traper Sverre Hansen ${ }^{22}$.

\section{Cel wyprawy}

Cel wyprawy został opisany we wspomnianym powyżej piśmie Sawickiego. Uczestnicy, korzystając z obecności kilku lodowców oraz dość szerokiego przedpola przed ich czołami, mieli przeprowadzić liczne badania z zakresu glacjologii arktycznej: zjawisk niwacji, odpływu wód lodowcowych, akumulacji, stratygrafii utworów peryglacjalnych i lodowcowych, morfologii itd. Badania te miały umożliwić poznanie genezy osadów i form lodowcowych oraz kształtowania się krajobrazu lodowcowego i peryglacjalnego w warunkach klimatu polarnego. Dzięki tym badaniom ekspedycja miała przyczynić się do lepszego zrozumienia zlodowacenia Polskiego Niżu, do lepszej interpretacji utworów tego zlodowacenia i ze zlodowaceniem tym związanych. Była także okazją do zdobycia dodatkowej wiedzy przez kilku uczonych badających problemy przeszłości geologicznej Polskiego Niżu²3.

Geograficzne" 1963 t. 34 z. 3 s. 327-328.

17 T. Gerlach: Mieczysław Klimaszewski - jego życie i praca, „Czasopismo Geograficzne" 1997 t. 68 z. 1 s. 5-18; B. Iz maiłow, K. Krzemień: Mieczysław Klimaszewski (1908-1995) geograf, geomorfolog, [w:] A. Z e ma n e k (red.): Uniwersytet Jagielloński. Złota księga Wydziału Biologii i Nauk o Ziemi. Część I: Biografie uczonych, Księgarnia Akademicka Kraków 2000 s. 389-398.

${ }^{18}$ P. Köhler: Polska wyprawa na Spitsbergen w 1934 roku, „Kwartalnik Historii Nauki i Techniki" 2015 t. 60 nr 2 s. 117-140.

${ }^{19}$ P. Köhle r: Druga polska wyprawa na Spitsbergen (w 1936 roku), „Kwartalnik Historii Nauki i Techniki" 2016 t. 61 nr 4 s. 135-143.

${ }^{20}$ P. Kö hl e r: Polska wyprawa na Grenlandię w 1937 r., „Kwartalnik Historii Nauki i Techniki" 2017 t. 62 nr 4 s. 45-62.

${ }^{21}$ B. C h wa śc iń s ki: Stefan Bernadzikiewicz. W 40-lecie śmierci, „Taternik” 1980 t. $56 \mathrm{nr}$ 2 s. 67-68; S. Łas zki ewicz: Szef Bernadzikiewicz, [w:] S. Łas z ki ewicz: Szum młodości, Składnica Księgarska Edinburgh 1945 s. 75-84.

22 [an on i m ]: Wyprawa glacjologiczna na Spitsbergen..., s. 10-11.

${ }^{23}$ Tamże, s. 9; B. Halicki: Trzecia polska wyprawa na Spitsbergen, „Wiadomości Muzeum Ziemi" 1938 t. 1 nr 4 s. 119-122, cyt. 121; L. S a w i c ki : Polska wyprawa glacjologiczna w 1938 roku..., s. 404-405. 


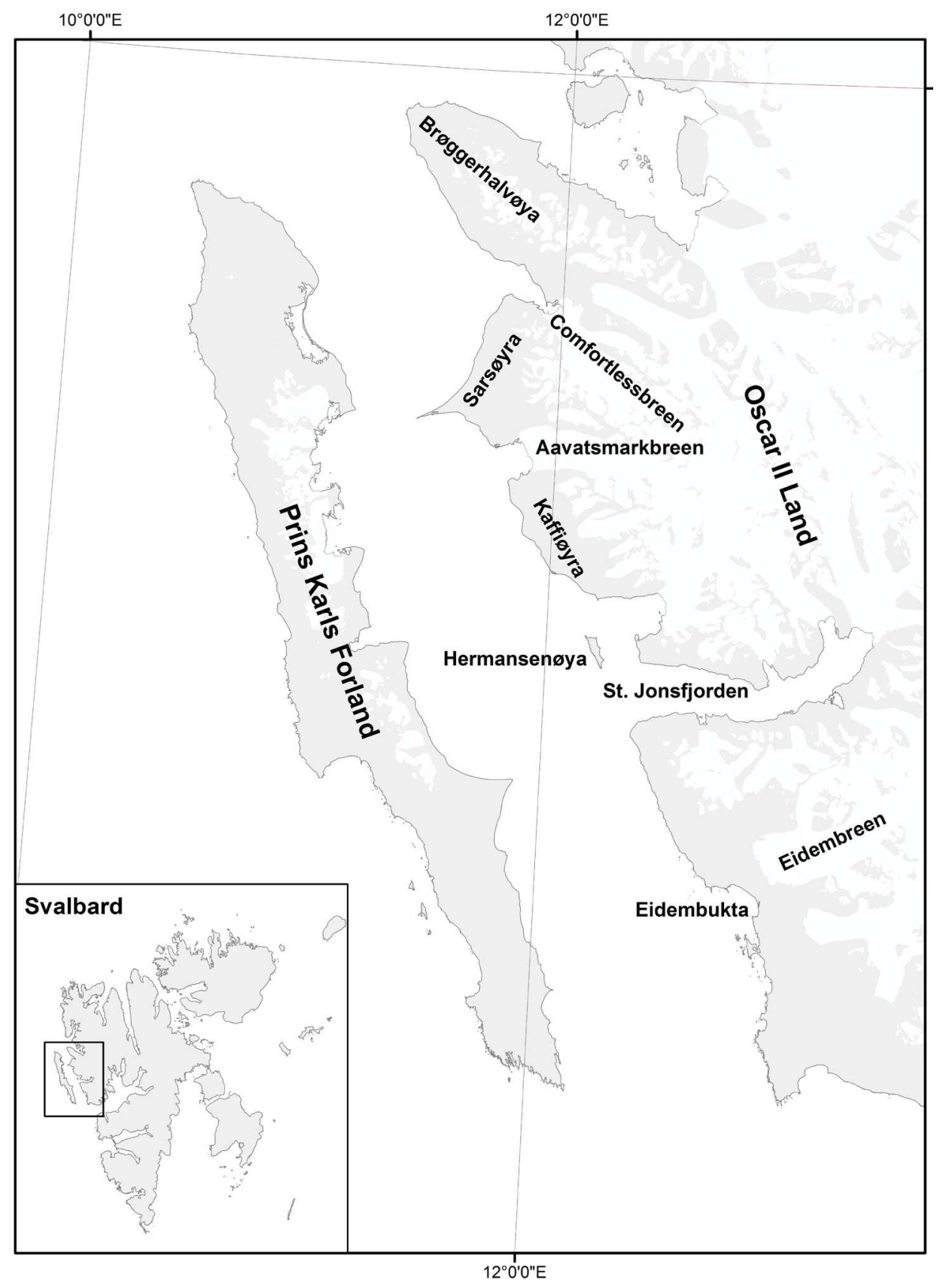

Ryc. 5. Teren działania wyprawy w Ziemi Oskara II na Spitsbergenie.

(C) Norwegian Polar Institute 2016) 


\section{Przebieg wyprawy}

Brak jest informacji o trasie podróży uczestników wyprawy z Polski na Spitsbergen. Nie wiadomo kiedy i z jakiego miasta w Polsce wyruszyli. Można domniemywać, że była to Warszawa, ponieważ mieszczący się w tym mieście Państwowy Instytut Geologiczny udzielił niezbędnego pomieszczenia na sprzęt obozowy w czasie organizowania wyprawy, jak i po jej zakończeniu ${ }^{24}$. Z uwagi na fakt, iż poprzednie wyprawy potrzebowały około 10 dni na podróż z Polski na Spitsbergen, uczestnicy tej wyprawy być może już koło 25-26 czerwca wyjechali z Polski. Do Norwegii udali się prawdopodobnie bezpośrednio z Gdyni przez Sztokholm ${ }^{25}$. Przypuszczalnie około 30 czerwca dojechali do Narviku, a stamtąd być może na pokładzie „Lyngena”, statku kursującego między Norwegią a Spitsbergenem, dotarli na ten archipelag. Nie wiadomo, ile mieli bagażu, ani jakim sprzętem naukowym dysponowali.

Prace terenowe trwały od 5 lipca do 6 września, jednak początkowo w trzyosobowym składzie: Bernadzikiewicz, Halicki i Sawicki. Czwarty z uczestników, Klimaszewski, dołączył do nich później, dopiero 29 lipca, ponieważ w lipcu prowadził wycieczkę naukową po Skandynawii ${ }^{26}$. Z kolei w dniu 24 sierpnia wyjechał Halicki ze względu na stan zdrowia ${ }^{27}$. Pozostali członkowie ekspedycji opuścili Spitsbergen 6 września 1938 r. ostatnim kursem „Lyngena”28. Prawdopodobnie około 10 dni później dotarli do Warszawy.

\section{Badania naukowe i ich rezultaty}

Wyprawa działała na Spitsbergenie w Ziemi Oskara II (ryc. 5). Teren ten nie był dziewiczy. Został już wcześniej przez Norwegów dobrze poznany i skartowany. Bazę założono w środkowej partii dość rozległej równiny o nazwie Kaffiøyra ${ }^{29}$, pomiędzy łańcuchami górskimi ciągnącymi się wzdłuż zachodnich brzegów głównej wyspy a cieśniną Forlandsundet, na skraju wąskiego pasa tundry opadającej niewysokim stopniem ku wybrzeżu morskiemu cieśniny. Tu w namiotach umieszczono bagaże i prowiant, tu również stanął szereg aparatów, przeważnie samopiszących, służących do obserwacji meteorologicznych ${ }^{30}$. W ocenie Sawickiego wybór równiny

${ }^{24}$ [a n o n im ]: Wyprawa glacjologiczna na Spitsbergen..., s. 11-12.

${ }^{25} \mathrm{Na}$ mapce zamieszczonej w anonimowej publikacji Wyprawa glacjologiczna na Spitsbergen..., s. 10 zaznaczono drogę wyprawy tylko ze Sztokholmu do Narviku.

${ }^{26}$ M. Kli m a s z e w s ki : Studia geomorfologiczne w zachodniej części Spitsbergenu..., s. 7.

27 [a n o n im]: Wyprawa glacjologiczna na Spitsbergen..., s. 9; L. Sawicki: Polska wyprawa glacjologiczna $w 1938$ roku..., s. 406. Poza tak ogólnie podaną przyczyną, brak innych informacji.

${ }^{28}$ M. Kli m a s z e w s ki: Studia geomorfologiczne w zachodniej części Spitsbergenu..., s. 7.

${ }^{29}$ Tak według współczesnej norweskiej ortografii. W polskich publikacjach z tamtego okresu używano zapisu: 'Kaffiöyra'.

${ }^{30}$ B. Hali cki : Trzecia polska wyprawa na Spitsbergen..., s. 120, 122 
Kaffiøyra na teren prac wyprawy okazał się trafny. Równina ta przedstawiała bowiem rozległe przedpole kilku lodowców, rozcięte szerokimi dolinami fluwioglacjalnymi, z jeziorkami i potokami, różnego typu gruntami strukturalnymi i utworami soliflukcyjnymi, a przed czołami lodowców - typowymi wałami utworów czołowo-morenowych ${ }^{31}$.

Pogoda, nawet jak na spitsbergeńskie warunki, była wtedy wyjątkowo niesprzyjająca. Być może dlatego w lipcu objęto badaniami tereny położone w stosunkowo niewielkiej odległości od bazy. W sierpniu natomiast odbywano dalsze, kilkudniowe wypady (nawet do $100 \mathrm{~km}$ ). Umożliwiała je wynajęta łódź motorowa sterowana przez wspomnianego już Norwega Sverre Hansena. Dokonywano także wycieczki piesze w głąb lądu, m.in. kilkakrotnie w poprzek półwyspu Brøggerhalvøya, przebyto też dział lodowy od uchodzącego do morza w zatoce Eidembukta wielkiego lodowca Eidembreen do fiordu St. Jonsfjorden ${ }^{32}$.

Uczestnicy wyprawy dysponowali mapami Isachsena z 1909 roku oraz Hoela z $1932 \mathrm{r}^{33}$. Wprawdzie program wyprawy nie przewidywał prac topograficznych, jednakże na miejscu okazało się, że są one potrzebne. Dlatego też podjęto pewne próby wykonania map szczegółowych ${ }^{34}$. Niestety, materiałów tych nie opublikowano. Najprawdopodobniej zaginęły w czasie wojny ${ }^{35}$.

Do głównych zagadnień badawczych poszczególnych uczestników wyprawy należały m.in. problem struktury i ruchu lodu lodowcowego, procesów prowadzących do tworzenia się różnych typów osadów i form morenowych (przede wszystkim moreny dennej i moren bocznych), rzeźbotwórczej roli wód rzeczno-lodowcowych i soliflukcji masowej. Badano również przekroje osadów zastoiskowych, morskich i lodowcowych, starając się odtworzyć geologiczną historię badanego odcinka terenu w najmłodszym okresie dziejów Ziemi. Dodać do tego należy jeszcze studia nad drobnymi formami powierzchniowymi powstającymi w osadach luźnych (żwiry, piaski, iły, zwietrzelina) przy współudziale lodu i wody wyłącznie w warunkach polarnych (gleby poligonalne, koła i smugi kamieniste) lub zależnie od tych warunków ${ }^{36}$.

Każdy z uczestników miał swobodę w zakresie realizacji programu wyprawy ${ }^{37}$. Klimaszewski zajmował się głównie zlodowaceniem obszaru górskiego, Sawicki genezą równin położonych przed czołem lodowców, a Halicki - problemami sedymentacji związanej z topnieniem lodowców, głównie w ich strefie marginalnej ${ }^{38}$.

${ }^{31}$ L. S aw i cki : Polska wyprawa glacjologiczna w 1938 roku..., s. 408.

${ }^{32}$ B. Halicki: Trzecia polska wyprawa na Spitsbergen..., s. 122.

${ }^{33}$ L. S aw icki: Na Spitsbergen..., cyt. nr 138 s. 6

${ }^{34}$ L. Sawicki: Polska Ekspedycja Glacjologiczna na Spitsbergen w roku 1938, „Przegląd Geograficzny" 1938 t. 18 s. 209-211, cyt. s. 210.

${ }^{35}$ K. R. L a n ka u f: Recesja lodowców rejonu Kaffiøyry..., s. 21.

${ }^{36}$ B. Hali c ki: Trzecia polska wyprawa na Spitsbergen..., s. 120.

${ }^{37}$ L. S a wi icki: Polska wyprawa glacjologiczna w 1938 roku..., s. 408

${ }^{38}$ Z. Wó j c i k: Zarys osiagnnięć..., s. 205. 
Rezultaty wyprawy zostały szczegółowo opisane przez Zbigniewa Wójcika w rozdziale Zarys osiągnięć polskiej wyprawy glacjologicznej na Spitsbergen w $1938 \mathrm{r}$. zawartym w opracowaniu zbiorowym Dzieje polskich, rosyjskich i radzieckich badań polarnych opublikowanym w $1982 \mathrm{r}^{39}$. Publikacja ta nie należy do częstych, dlatego poniżej przytaczam główne ustalenia Z. Wójcika.

Klimaszewski w badaniach (w których był wspierany okresowo przez Halickiego i Bernadzikiewicza) zajął się zagadnieniem genezy moren dennych, bocznych i czołowych, a zwłaszcza zdiagenizowanymi morenami ablacyjnymi. Moreny czołowe lodowców Comfortlessbreen i Elisebreen zostały przez niego pomierzone tachimetrycznie. Przeprowadzał także obserwacje działalności erozyjnej i akumulacyjnej rzek i wód spływających z lodowca, roli lodu martwego w morfologii przedpola lodowców, procesów soliflukcyjnych oraz sposobu cofania się lodowców w zależności od konfiguracji podłoża ${ }^{40}$.

W rezultacie tych prac powstało bardzo cenne studium geomorfologiczne wraz z mapą poświęcone obszarowi położonemu między fiordem Kongsfjorden a zatoką Eidembukta ${ }^{41}$. Opublikowane zostało dopiero 22 lata po wyprawie - w $1960 \mathrm{r}$. Klimaszewski na podstawie swych badań wydzielił regiony geomorfologiczne badanego terenu, wyróżnił cechy wspólne dla procesów formowania się krajobrazu lodowcowego na Spitsbergenie i w Polsce. Stwierdził, że poruszający się lodowiec przeważnie dostosowuje się do podłoża w strefie brzeżnej, dlatego w tej strefie nie przejawia on działalności niszczącej. Tym tłumaczył słabe ślady przeobrażenia glacjalnego obszarów położonych w zasięgu brzeżnych części lodowców skandynawskich w Karpatach i na wyżynach w Polsce ${ }^{42}$. Zwrócił uwagę na występowanie pseudomorenowych wałów czołowych i bocznych, zbudowanych z grubego materiału moreny powierzchniowej spoczywającego na czole i bokach lodowca, oraz formowanie z nich wałów morenowych, które jednak nie znaczą postojów recesyjnych (np. w Tatrach) ${ }^{43}$. Zmiany sieci rzecznej oraz powstawanie przełomów odziedziczonych wiązał z rolą rzek marginalnych zasilanych przez rzeki proglacjalne. Mają one ważne znaczenie $\mathrm{w}$ formowaniu się większych obniżeń $\mathrm{z}$ towarzyszącymi im wałami morenowymi. Niekiedy następuje w takich przypadkach przeciąganie wód do zagłębień ablacyjnych, przy czym rzeki wykorzystują zwykle poprzednio powstałe przełomy - tzn. przełomy odziedziczone. Taką genezę miały mieć przełomowe odcinki dolin w obrębie Niżu Polskiego oraz wielkie zmiany hydrograficzne na tym obszarze ${ }^{44}$.

\footnotetext{
${ }^{39}$ Tamże.

${ }^{40}$ [a n o n im ]: Wyprawa glacjologiczna na Spitsbergen..., s. 10.

${ }^{41}$ M. Klim a s zew s ki : Studia geomorfologiczne w zachodniej części Spitsbergenu....

${ }^{42}$ Z. Wó j ci k: Zarys osiągnięć..., 211-212.

${ }^{43}$ Tamże, 212.

${ }^{44}$ Tamże.
} 
Najważniejsze spostrzeżenia Klimaszewskiego dotyczą intensywności procesów peryglacjalnych oraz rozmiarów przeobrażenia rzeźby starszej. W świetle badań w zachodniej części Spitsbergenu stwierdził, że rozmiary przeobrażenia rzeźby Polski, zwłaszcza Niżu, przez procesy peryglacjalne są ocenione za wysoko, a intensywność tych procesów przeceniana ${ }^{45}$. Różnice w odmiennym wykształceniu się współczesnych szczelin i klinów mrozowych na Spitsbergenie oraz szczelin kopalnych w Polsce interpretował jako rezultat różnic klimatycznych: na obecnych terenach Polski w plejstocenie panował klimat bardziej suchy, kontynentalny, podczas gdy współcześnie na Spitsbergenie panuje klimat wilgotny, oceaniczny. Interpretacja ta został potwierdzona przez późniejszych badaczy ${ }^{46}$.

Według anonimowego autora sprawozdania z wyprawy ${ }^{47}$ Klimaszewski obserwacje wykonane podczas jej trwania wykorzystał jeszcze przed II wojną światową przy opracowaniu utworów soliflukcyjnych w Krościenku w części geologicznej pracy pt. Flora dryasowa z ostatniego zlodowacenia $w$ Krościenku ${ }^{48}$ oraz w badaniach nad „formami wymarzania dyluwialnego koło Krakowa” ${ }^{49}$. Także w swym podręczniku geomorfologii ${ }^{50}$ Klimaszewski wielokrotnie powołuje się na wyniki badań wyprawy na Spitsbergen w $1938 \mathrm{r}^{51}$.

Drugi z uczestników ekspedycji - Sawicki - w badaniach skupił się na zagadnieniach stratygrafii i morfologii przedpola lodowców równiny Kaffiøyra, charakteru i morfologii utworów występujących przed czołem lodowców oraz utworów fluwioglacjalnych. L. Sawicki tak opisuje własne badania prowadzone podczas wyprawy:

Prace swoje ograniczyłem głównie do terenu Kaffiöyry. Jedynie dla poznania w celach porównawczych stosunków charakteryzujących tereny przyległe i poczynienia obserwacji uzupełniających - odbyłem szereg wycieczek: na wyspy Hermansenöya i Księcia Karola (Prinz Karl Forland), na równinę Sarsöyrapraz na przedpole lodowca Comfortless w Zatoce Angielskiej. W swoich badaniach ograniczyłem się do zagadnień: stratygrafii i morfologii przedpola oraz strefy recesywnej lodowców równiny Kaffiöyra i lodowca Comfortless, morfologii i stratygrafii utworów morenowo-czołowych, lodu martwego, wpływu wiecznie zmarzłego gruntu (marzłoci) na rozwój procesów erozyjnych i morfologię dolin fluwioglacjalnych, zaburzeń mrozowych

45 Tamże, s. 212-213.

${ }^{46}$ Tamże, s. 213-214.

47 [anonim]: Wyprawa glacjologiczna na Spitsbergen..., s. 12.

${ }^{48}$ M. Kl im as ze ws ki, W. Sz a fer, B. Szafra n, J. U rb ań ski.: Flora dryasowa $w$ Krościenku nad Dunajcem (The Dryas-flora of Krościenko on the river Dunajec), „Biuletyn Państwowego Instytutu Geologicznego” 1939 (1950) nr 24 s. 5-86. Nr 24 „Biuletynu Państwowego Instytutu Geologicznego" wydany został tuż przed II wojną światową. Większość nakładu w czasie wojny uległa zniszczeniu, dlatego numer ten wydano po raz drugi. Korzystałem $\mathrm{z}$ tego drugiego wydania.

${ }^{49}$ Nie znalazłem takiej pracy.

${ }^{50}$ M. Kli mas zewski: Geomorfologia, PWN Warszawa 1978, 1098 s.

${ }^{51}$ Z. Wó j c i k: Zarys osiagnnięć.., s. 214-215. 
gruntów, deflacji i akumulacji eolicznej. W badaniach stratygraficznych korzystałem nie tylko z odsłonięć naturalnych, lecz również sztucznych, stosując kopanie szurfów i szybików (osobiście, ekspedycja w swym składzie pracownika fizycznego nie miała). Znaczna część równiny Kaffiöyry, objęta dolinami fluwioglacjalnymi lodowców Ireny i Elizy, została przeze mnie szczegółowo tachymetrycznie zdjęta w skali 1: 25000, zniwelowana i związana z tymi lodowcami. Ważnym wynikiem badań stratygraficznych było stwierdzenie obecności śladów zlodowacenia plejstoceńskiego, które pokrywało całkowicie tę część Zachodniego Spisbergenu. W rezultacie wykonanych prac, prócz licznych notatek polowych i uzupełniających je 153 zdjęć fotograficznych (statywowych, o wym. 10 x $15 \mathrm{~cm}$ ), zgromadziłem ok. 400 kg (brutto) próbek różnych utworów czwartorzędowych i materiału narzutowego, których ostatnia wojna nie zniszczyła ${ }^{52}$.

W notatce z 1959 r. (z której pochodzi powyższy cytat) zaznaczył, że z powodu krótkiego czasu trwania ekspedycji, ograniczył zakres swych badań pod względem tematycznym do analizy form niezbyt rozległego obszaru słabo zlodowaconego. Dzięki temu uzyskał na drodze porównawczej lepsze zrozumienie przebiegu pewnych procesów w okresie zlodowacenia obszarów niżowych w Polsce $^{53}$.

Trzeci z uczestników - Halicki - prowadził badania naukowe nad budową geologiczną równiny Kaffiøyra i przylegającej do niej od północy (poprzez lodowiec Aavatsmarka) równiny Sarsøyra oraz obszarów sąsiednich, ze szczególnym uwzględnieniem czwartorzędu. Następnie - nad rozmieszczeniem materiału skalnego w lodowcach, tworzeniem się osadów lodowcowych, zastoiskowych i soliflukcją oraz powstaniem i przeobrażaniem się krajobrazu lodowcowego. Udało mu się także poczynić obserwacje nad ozami i formami drumlinoidalnymi ${ }^{54}$.

Dane uzyskane podczas wyprawy Halicki wykorzystał w kilku publikacjach. W artykule pt. $O$ lodowcach ${ }^{55}$ opisuje ruch lodowca polarnego podczas wysokiej temperatury trwającej kilka dni podczas lata polarnego. Ruch ten jest w takich warunkach znacznie przyspieszony i powoduje skokowe zmiany w położeniu czoła lodowca. Spostrzeżenie to miało istotne znaczenie dla zrozumienia procesów nasuwania się lodowców także na Niż Polski. Było to tym ważniejsze, że wcześniej uważano, że lodowiec skandynawski posuwał się na południe całą swą masą. Spostrzeżenia spitsbergeńskie Halickiego pozwoliły zwrócić uwagę na rolę jęzorów lodowcowych wychodzących daleko przed czoło pokrywy lądolodu. Dopiero po latach wykazano, że tak było istotnie, głównie na Wyżynie Krakowsko-Częstochowskiej i w Górach Świętokrzyskich. Duże znaczenie poznawcze miały także fotografie zamieszczone $w$ tym artykule pokazujące m.in. lodowiec wylewający się

\footnotetext{
${ }^{52}$ L. Sa wi cki : Polska wyprawa glacjologiczna w 1938 roku..., s. 410.

${ }^{53} \mathrm{Z}$. Wó j ci k: Zarys osiagnięć.., s. 216.

${ }^{54}$ [a n o n im ]: Wyprawa glacjologiczna na Spitsbergen..., s. 10.

${ }^{55}$ B. Hali cki : O lodowcach, „Wiadomości Muzeum Ziemi”1949 t. IV (za 1948) s. 77-111.
} 


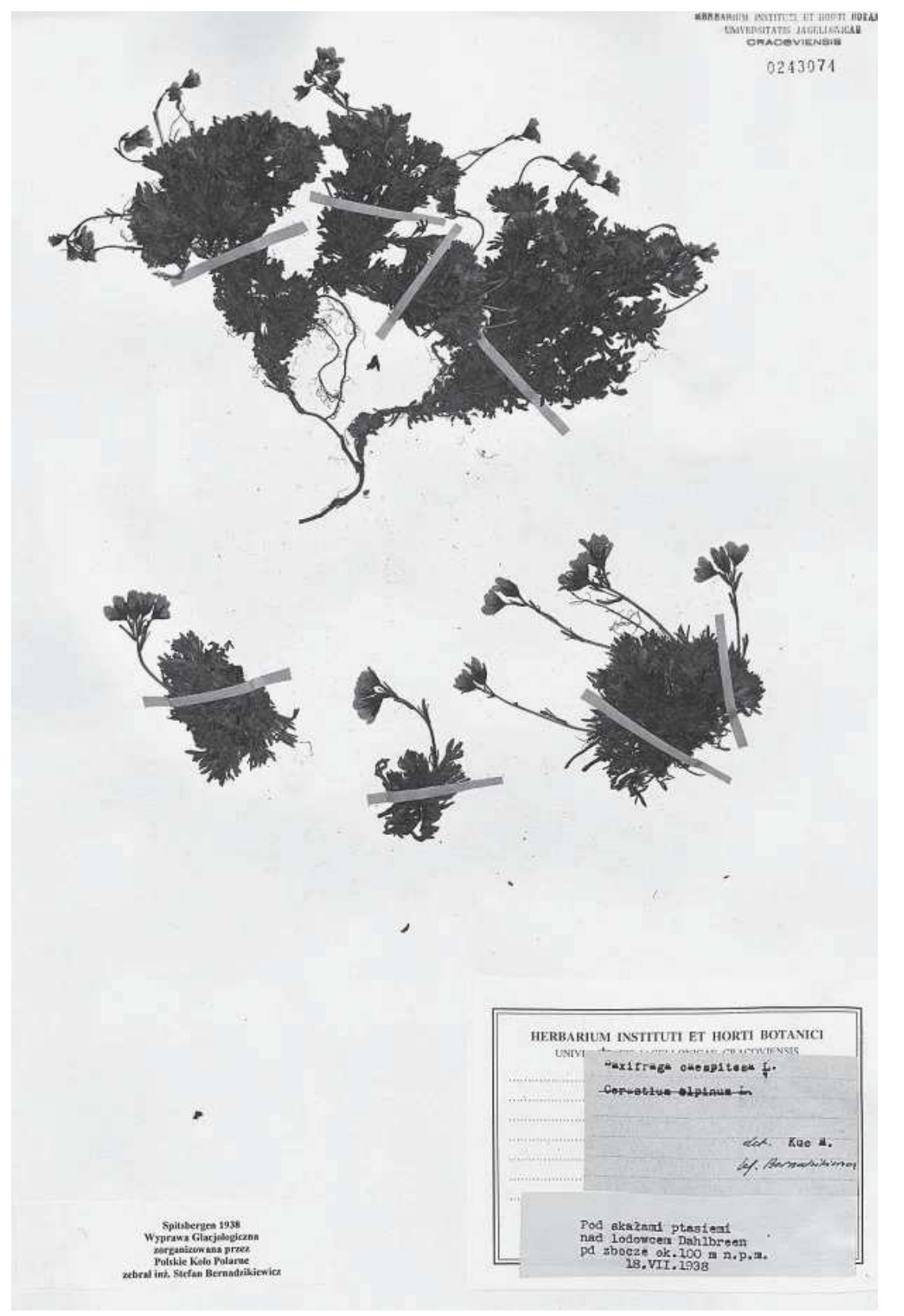

Ryc. 6. Arkusz zielnikowy z okazem skalnicy rozesłanej zebranym podczas wyprawy.

Treść etykiet: „Saxifraga caespitosa L. det.: Kuc M.; leg.: Bernadzikiewicz. Pod skałami ptasiemi nad lodowcem Dahlbreen pd zbocze ok. 100 m n.p.n.; 18.VII.1938” oraz „Spitsbergen 1938. Wyprawa Glacjologiczna zorganizowana przez Polskie Koło Polarne; zebrał inż. Stefan Bernadzikiewicz." Nr arkusza zielnikowego: KRA 0243074. Fot. dr Małgorzata Jaźwa 
z doliny na przedpole, strefy brzeżne lądolodu polarnego, czy martwy lód niszczony przez fale morskie ${ }^{56}$.

W artykule o strukturach „kutego srebra” 57 analizuje powstawanie tego typu struktur w lodzie oraz zjawiska związane z przeobrażaniem się i wietrzeniem lodu w lodowcach. Szczególną rolę przypisuje wietrzeniu występującego między kryształami lodu spoiwa zawierającego sól ${ }^{58}$.

Kolejnym artykułem, w którym Halicki wykorzystał swe doświadczenia zdobyte podczas wyprawy na Spitsbergen w 1938 r., była krótka publikacja pt. Rola lodu gruntowego $w$ kształtowaniu plejstoceńskich form peryglacjalnych ${ }^{59}$. Nie pisze tam wprawdzie bezpośrednio o Spitsbergenie, ale - jako pierwszy w Polsce - zwrócił uwagę na rangę procesów krasu termicznego w tworzeniu się „oczek” po wytopionych bryłach martwego lodu ${ }^{60}$. Z. Wójcik wspomina jeszcze o artykule pt. Zagadnienia genezy i wieku tzw. oczek lodowcowych ${ }^{61}$ Anny Kalniet. Autorka zaprezentowała w nim zarówno poglądy Halickiego na genezę tych oczek, jak też wykorzystała zdjęcia wykonane przez niego na Spitsbergenie w $1938 \mathrm{r}^{62}$.

Halicki materiału zebranego podczas wyprawy nie zdołał przygotować do druku. Jego spostrzeżenia miały natomiast istotny wpływ na ocenę procesów sedymentacji oraz stratygrafię osadów czwartorzędowych na Niżu Polskim. Fotografie wykonane przez niego i zamieszczone w sprawozdaniu z wyprawy ${ }^{63}$ oraz na wystawie $\mathrm{w}$ Muzeum Ziemi wpłynęły w dużym stopniu na świadomość polskich geologów na temat ogólnego wyglądu lodowców polarnych ${ }^{64}$.

Zasługą ostatniego z uczestników wyprawy - Bernadzikiewicza - była sprawna organizacja i przebieg wyprawy. W głównej bazie prowadził systematyczne badania meteorologiczne (mierzył wielkość opadów i nasłonecznienia oraz temperaturę) przy pomocy przyrządów wypożyczonych z Państwowego Instytutu Meteorologicznego. Wspomagał w pracach terenowych zwłaszcza Halickiego i Klimaszewskiego. Zebrał zielnik flory tundrowej (rośliny kwiatowe). Ponadto wykonał film (dł. negatywu ok. 1000 m) dokumentujący działalność i ruch lodowców stanowiący uzupełnienie odpowiednich obserwacji terenowych ${ }^{65}$.

\footnotetext{
${ }^{56}$ Z. Wó j ci k: Zarys osiagnięć.., s. 208-209.

${ }^{57}$ B. H a li c ki: Struktury „kutego srebra” na lodowinach w English Bay (West Spitsbergen), „Acta Geophysica Polonica” 1956 t. 7 s. 342-348.

${ }^{58} \mathrm{Z}$. Wó j ci k: Zarys osiagnię...

${ }^{59} \mathrm{~B}$. Halicki: Rola lodu gruntowego $w$ kształtowaniu plejstoceńskich form peryglacjalnych, „Acta Geologica Polonica” 1952 t. 2 s. 616-617.

${ }^{60} \mathrm{Z}$. Wó j ci k: Zarys osiągnięć...

${ }^{61}$ A. Kaln i et: Zagadnienia genezy i wieku tzw. oczek lodowcowych, „Wiadomości Muzeum Ziemi" 1952 t. 6 z. 2 s. 339-355; zdjęcia nr 1 i 2 wykonał B. Halicki na Spitsbergenie w 1938 r.

${ }^{62}$ Z. Wó j ci k: Zarys osiagnięć..., s. 209-210.

${ }^{63}$ B. Halic ki: Trzecia polska wyprawa na Spitsbergen..., fot. 16-18.

${ }^{64}$ Z. Wó j ci k: Zarys osiagnięć.., s. 207.

${ }^{65}$ [a n o n im ]: Wyprawa glacjologiczna na Spitsbergen..., s. 11.
} 


\section{Opracowania popularne, wspomnienia}

W przeciwieństwie do poprzednich polskich wypraw polarnych, wyprawa z 1938 r. nie doczekała się opracowań popularnych, które można by porównać do analogicznych opracowań poprzednich ekspedycji. Jej uczestnicy nie opublikowali swych dzienników wyprawowych ani wspomnień. Jedynym wyjątkiem jest Sawicki, który dopiero w artykule z 1959 r. zamieścił krótki fragment ze swego dziennika wyprawy $^{66}$. Ten sam autor w połowie lat pięćdziesiątych w związku z przygotowaniami do polskich wypraw do Hornsundu na Spitsbergenie opublikował w „Życiu Warszawy" trzyczęściową notatkę, w której przypominał o polskiej wyprawie z 1938 r. na Spitsbergen $^{67}$.

\section{Zbiory naukowe, archiwalia}

Podczas wyprawy jej uczestnicy gromadzili zbiory naukowe, prowadzili obserwacje i dokumentowali swe badania, m.in. wykonując fotografie. Od razu po powrocie do Polski przekazano ok. 400 kg próbek geologicznych Państwowemu Instytutowi Geologicznemu w Warszawie ${ }^{68}$. W połowie lat siedemdziesiątych XX w. Wójcik wykonał kwerendę w instytucjach naukowych znajdujących się na terenie Warszawy. Okazało się, że zbiory Halickiego uległy częściowemu zniszczeniu w czasie II wojny światowej. Pozostała część, obejmująca notatki i fotografie, znalazła się w Muzeum Ziemi PAN, gdzie nie była udostępniania. Gdy wiosną 2017 r. zapytałem o te materiały, otrzymałem odpowiedź negatywną: Muzeum Ziemi nie posiada spuścizny Halickiego, a jedynie „jakieś fotografie w większości nieopisane" ${ }^{69}$. Również zbiory Sawickiego zostały częściowo zniszczone, a pozostała część znajdująca się z posiadaniu rodziny nie była udostępniania ${ }^{70}$. Niewielka część trafiła do Państwowego Instytutu Geologicznego w Warszawie. Z informacji tam uzyskanych wynika, że zachowało się około 15 kości nieoznaczonych ssaków ${ }^{71}$. Spuścizna Klimaszewskiego przechowywana jest w Archiwum Uniwersytetu Jagiellońskiego, a niewielka jej część - w Archiwum Nauki PAN i PAU w Krakowie. Po sprawdzeniu okazało się, że nie ma w obu wspomnianych archiwach jego materiałów związanych z wyprawą na

${ }^{66}$ L. Sawicki: Polska wyprawa glacjologiczna w 1938 roku na Spitsbergen. (Kartki z Dziennika Wyprawy), „Acta Geophysica Polonica” 1959 t. 7 s. 405-418.

${ }^{67}$ L. Sawicki: Na Spitsbergen...

${ }^{68}$ [a n o n i m ]: Wyprawa glacjologiczna na Spitsbergen..., s. 11.

${ }^{69}$ Informacja pisemna uzyskana dn. 10 V 2017 r. od dr Agnieszki Pietrzak, kierownik Działu Historii Nauk o Ziemi i Biblioteki Muzeum Ziemi PAN, Aleja Na Skarpie 20/26, 27, 00-488 Warszawa.

${ }^{70}$ Z. Wó j c i k: Zarys osiągnięć.., s. 201-202, 221-222.

${ }^{71}$ Informacja pisemna z dn. 11 V 2017 r. uzyskana od dr Tatiany Woroncowej-Marcinowskiej z Muzeum Geologicznego Państwowego Instytutu Geologicznego - Państwowego Instytutu Badawczego, ul. Rakowiecka 4, 00-975 Warszawa. 
Spitsbergen w 1938 r. W Zakładzie Badań i Dokumentacji Polarnej im. Prof. Z. Czeppego Instytutu Botaniki Uniwersytet Jagiellońskiego przechowywane są szklane fotografie Klimaszewskiego ${ }^{72}$. Być może przynajmniej niektóre z nich są oryginalne, inne mogą być kopiami z wcześniejszych publikacji.

Zielnik zebrany przez Bernadzikiewicza został przekazany do dalszego opracowania Władysławowi Szaferowi (1886-1970), dyrektorowi Instytutu Botanicznego Uniwersytetu Jagiellońskiego. Obecnie kolekcja ta jest w Zielniku Instytutu Botaniki UJ (KRA). Sprawdzenie poprawności oznaczeń poszczególnych okazów roślin składających się na to herbarium zostało dokonane przez znanego botanika-polarnika Mariana Kuca (1932-2011) ${ }^{73}$, jednakże nie zanotowano na etykietach zielnikowych, kiedy to nastąpiło (Ryc. 6). Niestety, herbarium to zostało włączone do zbioru głównego Zielnika Instytutu Botaniki UJ bez wcześniejszego sporządzenia szczegółowego spisu arkuszy zielnikowych i gatunków je tworzących. Dlatego obecnie na razie trudno powiedzieć, jak wielki był to zbiór ${ }^{74}$. Z dużą dozą prawdopodobieństwa można natomiast stwierdzić, że herbarium to nie zawierało mszaków, a jedynie rośliny kwiatowe ${ }^{75}$.

Bernadzikiewicz nakręcił film (ok. 1000 m b. negatywu) dokumentujący głównie działalność i ruch lodowców. Na razie nic nie wiadomo na temat tego filmu. W Filmotece Narodowej brak o filmie informacji ${ }^{76}$. Należy przypuszczać, że jeśli film po powrocie z ekspedycji został wywołany, a nie zachował się o nim do dziś żaden ślad, to najprawdopodobniej nie przetrwał II wojny światowej.

\section{Podsumowanie}

Ostatnia polska wyprawa na Spitsbergen w okresie międzywojennym pozostaje w cieniu poprzednich. Wybuch II wojny światowej miał na to główny wpływ. Wojna przerwała bowiem na długie lata możliwość opracowania, a następnie przygotowania do druku zebranych materiałów. Dziś, po upływie wielu lat od zakończenia ekspedycji, można stwierdzić, że pomimo ciężkich warunków terenowych i klimatycznych, w jakich pracowała polska wyprawa na Spitsbergenie w 1938 r., materiał naukowy zebrany przez jej uczestników jest naprawdę znaczący. Główne zadanie ekspedycji, jakim było zebranie możliwie dużej ilości danych do celów porównaw-

72 Zakł. Bad. i Dok. Polar. IB UJ, sygn. 5.I.8.

${ }^{73}$ R. O c hy ra: A tribute to Marian Piotr Kuc (1932-2011), „Polish Botanical Journal” 2012 t. 57 nr 1 s. $3-20$.

${ }^{74}$ Być może w przyszłości, gdy cały Zielnik Instytutu Botaniki UJ (KRA) zostanie skomputeryzowany, będzie można podać dokładne dane na temat wielkości tego zbioru.

${ }^{75}$ Informacja uzyskana od prof. Haliny Bednarek-Ochyry z Instytutu Botaniki PAN opiekującej się także zbiorami mszaków UJ.

${ }^{76}$ Informacja pisemna uzyskana dn. 10 V 2017 r. od pani Danuty Pawłowskiej z Zespołu Obsługi Klienta Filmoteki Narodowej, ul. Chełmska 21, 00-724 Warszawa. 
czych oraz poznanie „klucza” umożliwiającego badania osadów plejstoceńskich w Polsce, zostało osiągnięte ${ }^{77}$. Taki cel jednocześnie sprawił, że dorobek publikacyjny tej ekspedycji jest ilościowo stosunkowo skromny. W ocenie Wójcika:

cała trójka uczestników dokonała swoistej rewolucji w zakresie wprowadzania nowych metod badawczych. Doświadczenia Klimaszewskiego i Halickiego zdobyte podczas badań zlodowaconych łańcuchów górskich na Spitsbergenie zaowocowały licznymi opracowaniami dotyczącymi zlodowaceń na terenie Tatr. Szczegółowe prace na przedpolu lodowców prowadzone przez Halickiego i Sawickiego zostały później wykorzystane $w$ badaniach nad najmłodszymi zlodowaceniami oraz postglacjałem i holocenem na Wyżynach Polskich (Sawicki) i Niżu Polskim (Sawicki i Halicki). Powszechnie przyjęto, zarówno wśród badaczy geologii czwartorzędu, jak i archeologów, zastosowane przez Sawickiego szczegółowe ryciny przekrojów geologicznych w badaniach osadów czwartorzędowych ${ }^{78}$.

Niestety, poza Klimaszewskim, pozostali uczestnicy wyprawy nie pozostawili po sobie, z wyjątkiem drobnych przyczynków, żadnej monografii badanego obszaru. Wójcik szacuje, że ich badania terenowe na Spitsbergenie mimo to miały ogromne znaczenie poznawcze: pozwoliły im właściwie ocenić dynamikę procesów sedymentacji w strefie czołowo-lodowcowej oraz na przedpolu lodowca. Miało to ogromne znaczenie dla późniejszych interpretacji profilów geologicznych na Niżu Polskim zarówno staroczwartorzędowych (Halicki), jak i młodoplejstoceńskich oraz holoceńskich (Sawicki). Wypracowanie metod badań sedymentacji proglacjalnej w odpowiednio dobranym terenie współczesnego zlodowacenia jest bez wątpienia jednym z największych sukcesów polskiej wyprawy na Spitsbergen w 1938 r. $^{79}$.

Podziękowania. Prof. dr hab. Wiesław Ziaja z Instytutu Geografii i Gospodarki Przestrzennej Uniwersytetu Jagiellońskiego był łaskaw sprawdzić poprawność merytoryczną niniejszego artykułu pod względem geograficzno-geomorfologicznym. Jestem Mu za to bardzo wdzięczny. Dr. Michałowi Węgrzynowi z Instytutu Botaniki UJ dziękuję za wykonanie mapy Spitsbergenu.

\footnotetext{
${ }^{77}$ Z. Wó j c i k: Zarys osiagnięć..., s. 217.

${ }^{78}$ Tamże, s. 217-218.

${ }^{79}$ Tamże, s. 221
} 


\section{BIBLIOGRAFIA}

[anonim]: II Polska wyprawa na Spitsbergen 1936 r., „Taternik” 1936 t. 21 nr 1 s. 11-12.

[anonim]: Wyprawa glacjologiczna na Spitsbergen. 5 czerwiec - 6 wrzesień 1938 r., „Wyprawy i Podróże. Biuletyn Polskiego Towarzystwa Wypraw Badawczych" 1939 nr 1 s. 9-12.

Bernadzikiewicz S.: II Polska wyprawa na Spitsberg, „Turysta w Polsce” 1936 t. 2 nr 11 s. $10-11$.

Bernadzikiewicz S.: Wielki sukces polskiej wyprawy Polarnej, „Ilustrowany Kuryer Codzienny" (Kraków) 1937 (22 X) s. 22.

Ch w a śc iń s ki B.: Stefan Bernadzikiewicz.W 40-lecieśmierci, „Taternik” 1980 t. 56 nr 2 s. 67-68.

Dąbrowski Z.: Polska wyprawa na Spitsbergen 1936 r., „Taternik” 1936 t. 20 nr 6 s. 220-221.

Dobrowolski A. B.: Pierwsza polska wyprawa do Grenlandii zachodniej, „Wiedza i Życie” 1948 t. 17 nr 6-7 s. 605-608.

Dylik J.: Dr Bronisław Halicki - profesor Uniwersytetu Warszawskiego, „Czasopismo Geograficzne" 1963 t. 34 z. 3 s. 327-328.

Gaweł A.: Z dziennika wyprawy naukowej na Grenlandię w 1937 roku, „Prace Muzeum Ziemi" 2001 t. 46 s. 171-184.

Gerlach T.: Mieczysław Klimaszewski - jego życie i praca, „Czasopismo Geograficzne” 1997 t. 68 z. 1 s. $5-18$.

Górski M.: Zimowanie 1932/1933 na Wyspie Niedźwiedziej - eksplozja polskich badań polarnych. „Przegląd Geofizyczny” 2015 nr 1-2 s. 59-76.

Gurgul H., Krzeptowski M.: Henryk Mogilnicki (1906-1999) w 65-lecie Polskiej Wyprawy na Spitsbergen. „Biuletyn Polarny” 2000 nr 8 s. 48-49.

Halicki B.: O lodowcach, „Wiadomości Muzeum Ziemi” 1949 t. IV (za 1948) s. 77-111.

Halicki B.: Rola lodu gruntowego w kształtowaniu plejstoceńskich form peryglacjalnych, „Acta Geologica Polonica” 1952 t. 2 s. 616-617.

Halicki B.: Struktury „kutego srebra” na lodowinach w English Bay (West Spitsbergen), „Acta Geophysica Polonica” 1956 t. 7 s. 342-348.

Halicki B.: Trzecia polska wyprawa na Spitsbergen, „Wiadomości Muzeum Ziemi” 1938 t. 1 nr 4 s. 119-122.

Izmaiłow B., Krzemień K.: Mieczysław Klimaszewski (1908-1995) geograf, geomorfolog, [w:] A. Zemanek (red.): Uniwersytet Jagielloński. Złota księga Wydziału Biologii i Nauk o Ziemi. Część I: Biografie uczonych, Księgarnia Akademicka Kraków 2000 s. 389-398.

Jahn A.: Grenlandia Zachodnia terenem polskiej wyprawy naukowej, „Wszechświat” r. 1938 nr 3 s. 67-73.

Kl i m a s z e w s k i M., S z a f e r W., S z a fr a n B., U r b a ń s k i J., Flora dryasowa w Krościenku nad Dunajcem (The Dryas-flora of Krościenko on the river Dunajec), „Biuletyn Państwowego Instytutu Geologicznego" 1939 (1950) nr 2486 s.

Kalniet A.: Zagadnienia genezy i wieku tzw. oczek lodowcowych, „Wiadomości Muzeum Ziemi" 1952 t. 6 z. 2 s. 339-355.

Klimaszewski M.: Geomorfologia, PWN Warszawa 19781098 s.

Klimaszewski M.: Studia geomorfologiczne w zachodniej części Spitsbergenu między Kongs-Fjordem a Eidem-Bukta, „Zeszyty Naukowe Uniwersytetu Jagiellońskiego 32, (Prace Instytutu Geograficznego UJ 23) Prace Geograficzne - Seria Nowa" 1960 t. 1 s. 1-167. 
Köhler P.: Druga polska wyprawa na Spitsbergen (w 1936 roku), „Kwartalnik Historii Nauki i Techniki" 2016 t. 61 nr 4 s. 135-143.

Köhler P.: Druga polska wyprawa na Spitsbergen (w 1936 roku). The second Polish expedition to Spitsbergen (in 1936), [w:] Ł. Franczak, G. Gajek (red.): XXXVI Sympozjum Polarne "Progress in polar research - new experiences and challenges" 30-lecie Wypraw Polarnych UMCS na Spitsbergen. Książka streszczeń, Wydział Nauk o Ziemi i Gospodarki Przestrzennej UMCS, Lublin 2016, s. 53.

Köhler P.: Osiemdziesięciolecie polskiej wyprawy na Wyspę Niedźwiedziq̨. „Biuletyn Polarny" 2014 nr 17-18 s. 62-66.

Köhler P.: Pierwsza polska wyprawa polarna. „Kwartalnik Historii Nauki i Techniki” 2013 t. $58 \mathrm{nr} 4$ s. 43-59.

Köhler P.: Polish expedition to Torell Land, Spitsbergen, in 1934 in the light of archival materials. [w:] K. Migała, M. C. Strzelecki, P. Owczarek, T. Sawiński, M. Korzystka-Muskała, P. Muskała, M. Kasprzyk (red.): Book of abstracts. 35th Polar Symposium Diversity and state of polar ecosystems. 4th-7th June 2014, Wrocław. Institute of Geography and Regional Development, University of Wrocław, Wrocław 2014 s. 62.

Köhler P.: Polska wyprawa na Grenlandię w 1937 r., „Kwartalnik Historii Nauki i Techniki” 2017 t. 62 nr 4 s. 45-63.

Köhler P.: Polska wyprawa na Spitsbergen w 1934 roku, „Kwartalnik Historii Nauki i Techniki" 2015 t. 60 nr 2 s. 117-140.

Köhler P.: The first Polish expedition to the Arctic. [w:] The Arctic Science Summit Week 2013 "The Arctic Hub Regional and Global Perspectives", 13-19 April 2013, Kraków, Poland. 2013 [publikacja elektroniczna], s. 1.

Köhler P.: Z Legionowa na Wyspę Niedźwiedzią. I polska wyprawa polarna 1932-1933. „Rocznik Legionowski” 2014 t. 7 s. 30-38.

Köhler P., Korczak-Abshire M.: Sesja naukowa „Znaczenie pierwszej wyprawy polarnej z Polski niepodległej”. Jubileusz 80-lecia Polskiej Ekspedycji II Międzynarodowego Roku Polarnego 1932/1933 na Wyspę Niedźwiedziq̨. „Kwartalnik Historii Nauki i Techniki” 2013 t. 58 nr 2 s. $268-271$.

Kosiba A.: I. polska wyprawa na Grenlandię, „Czasopismo Geograficzne” 1937 t. 15 nr 3 s. 209-213.

Kosiba A.: Mapa pierwszej wyprawy naukowej na Grenlandię, „Czasopismo Geograficzne” 1939 t. 17 nr 1 s. 37-38.

Kosiba A.: O udziale Polaków w badaniach Grenlandii, „Czasopismo Geograficzne” 1973 t. $44 \mathrm{nr} 2$ s. $147-188$.

[Kosiba A.]: Polish Expedition to West Greenland, 1937, „The Polar Record” (Scott Polar Research Institute, Cambridge) 1938 t. 2 nr 14 s. 117-118, nr 15 s. 25-27.

Kosiba A.: Polska wyprawa na Grenlandię wr. 1937. (Komunikat wstępny). Polish Greenland - expedition. (Preliminary report), Towarzystwo Geograficzne we Lwowie [Lwów 1937] $8 \mathrm{~s}$.

Krawczyk A.: Polskie ślady na Wyspie Niedźwiedziej (1932-1933). „Biuletyn Polarny” $2014 \mathrm{nr}$ 17-18 s. 73-75.

Lankauf K. R.: Recesja lodowców rejonu Kaffiøyry (Ziemia Oskara II -Spitsbergen) w XX wieku. The retreat of the glaciers in the Kaffiøyra region (Oscar II Land - Spitsbergen) in the twentieth century, „Prace Geograficzne - Geographical Studies” 2002 t. 183221 s. + [18] k. tabl., [6] k. map złoż.

Łaszkiewicz S.: Szef Bernadzikiewicz, [w:] S. Łaszkiewicz: Szum młodości, Składnica Księgarska Edinburgh 1945 s. 75-84. 
Maj S.: Pierwsza polska wyprawa polarna na Wyspę Niedźwiedzią (1932-1933). „Przegląd Geofizyczny" 2014 nr 3-4 s. 175-186.

Pillewizer W.: Die kartographischen und gletscherkundlichen Ergebnisse der deutschen Spitzbergen-Expedition 1938, Justus Perthes Verlag Gotha 1939 s. 1-46.

Ruthe K.: Bericht über die kartographischen und gletscherkundlichen Ergebnisse der Deutschen Spitzbergen-Expedition 1938, „Polarforschung” (Bremerhaven) 1941 t. 11 nr 1 s. 6-8.

Sawicki L.: Na Spitsbergen. Polska wyprawa glacjologiczna 1938 r., „Życie Warszawy” 1956 nr 132 (3-4 VI 1956) s. 6, nr 138 (10-11 VI 1956) s. 6, nr 144 (17-18 VI 1956) s. 6.

Sawicki L.: Polska Ekspedycja Glacjologiczna na Spitsbergen w roku 1938, „Przegląd Geograficzny" 1938 t. 18 s. 209-211.

Sawicki L.: Polska wyprawa glacjologiczna w 1938 roku na Spitsbergen. (Kartki z Dziennika Wyprawy), „Acta Geophysica Polonica” 1959 t. 7 s. 405-418.

Siedlecki S.: Przejście z południa na północ przez Zachodni Spitsbergen, „Wierchy” 1938 t. 16 s. $118-135$.

Szupryczyński J.: Pierwsza polska wyprawa polarna na Spitsbergen. „Przegląd Geograficzny" 2015 t. $87 \mathrm{nr} 1$ s. 167-178.

Szupryczyński J.: Pierwsza polska wyprawa polarna. „Przegląd Geograficzny” 2013 t. 85 nr 1 s. $123-130$.

Węglowski J.: Polskie Towarzystwo Wypraw Badawczych, [w:] B. Sordylowa (red. naukowy): Słownik Polskich Towarzystw Naukowych, t. II Towarzystwa naukowe i upowszechniające naukę działające $w$ przeszłości na ziemiach polskich część 1, Zakład Narodowy im. Ossolińskich Wydawnictwo PAN Wrocław - Warszawa - Kraków - Gdańsk - Łódź 1990 s. 262-263.

Wójcik Z. J.: Ludwik Sawicki. http://www.ipsb.nina.gov.pl/a/biografia/ludwik-sawicki [dostęp 24 III 2017]

Wój cik Z.: Zarys osiagnięć polskiej wyprawy glacjologicznej na Spitsbergen w $1938 \mathrm{r}$., [w:] Dzieje polskich, rosyjskich i radzieckich badań polarnych. Materiały III Sympozjum Polsko-Radzieckiego z Historii Nauk o Ziemi, Wrocław, 25-30 września 1978 r., Zakład Narodowy im. Ossolińskich, Wrocław - Warszawa - Kraków - Gdańsk - Łódź 1982, s. 201-227.

Zawadzki A. R.: Polska wyprawa na Grenlandię w 1937 r. Polish Greenland Expedition 1937, Nakładem Sekcji Wydawniczej Armii Polskiej na Wschodzie, [Palestyna] $194431 \mathrm{~s}$.

Zawadzki A.: Polska wyprawa na Grenlandię 1937, Nakł. Sekcji Geograficznej Tow. Wiedzy Wojskowej, Warszawa 1939 VI s. + nlb. $1+102+$ nlb. 1, tabl. 4, mapa 1. [Seria: Biblioteka Służby Geograficznej, t. 18].

Zawadzki A.: Polska Wyprawa na Grenlandię, „Wiadomości Służby Geograficznej” 1937 t. $11 \mathrm{nr} 2$ s. 235-237.

Zawadzki A.: Polska Wyprawa na Grenlandię w r. 1937, „Wiadomości Służby Geograficznej" 1938 t. 12 nr 1 s. 33-73, nr 2-3 s. 166-214, nr 4 s. 508-521.

Zawadzki A.: Prace polskiej wyprawy naukowej na Grenlandię w 1937 r., „Wiadomości Służby Geograficznej" 1937 t. 11 nr 3-4 s. 507-520. 